\title{
Impact of quality of iron ore lumps on sustainability of mining operations in the Quadrilatero Ferrifero Area
}

\author{
Reinaldo Brandao Gomes ${ }^{a, *}$, Giorgio D. Tomi ${ }^{b}$, Paulo S. Assis ${ }^{c}$ \\ a UFOP, Brazil \\ ${ }^{\mathrm{b}}$ University of São Paulo - USP, Brazil \\ ${ }^{c}$ Federal University of Ouro Preto - UFOP, Brazil
}

\section{A R T I C L E I N F O}

\section{Article history:}

Received 28 July 2014

Accepted 26 September 2014

Available online 25 October 2014

\section{Keywords:}

Mine systems

Iron ore lumps

Mineral processes

Sustainability

\begin{abstract}
A B S T R A C T
The quality of lumps may have a significant impact in iron ore mining systems with implications for mineral reserve recovery rates. Improving the quality of lump ore, through a simple yet innovative mineral processing, can maximize recovery of reserves, decrease waste generation, and increase the productivity and sustainability of mines by allowing transition to lower quality iron ores. An example of the application of such principle is described here in which both siliceous and dolomitic banded iron formation rocks (BIFs) were subjected to chemical, physical, and mineralogical characterization before undergoing beneficiation processes in pneumatic jigs and log washer equipment. These processes were found to increase product quality and reduce the levels of contaminants, including $\mathrm{SiO}_{2}, \mathrm{Al}_{2} \mathrm{O}_{3}$, and fines. The gain in quality led to a reduction in the cut-off grade, from $60 \%$ to $58 \% \mathrm{Fe}$, while maintaining products specifications. Consequently, a $20 \%$ increase in the lump ore reserves was achieved, contributing to the sustainability of the mining system.
\end{abstract}

(ㄷ) 2014 Elsevier Ltd. All rights reserved.

\section{Contents}

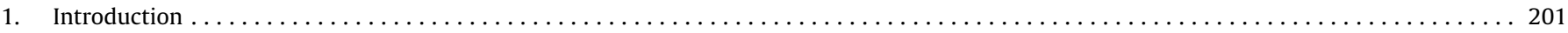

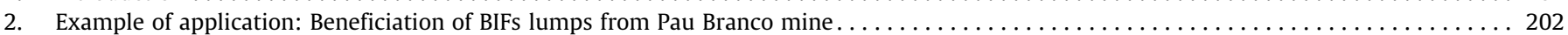

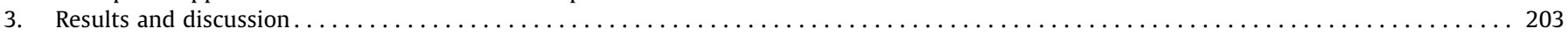

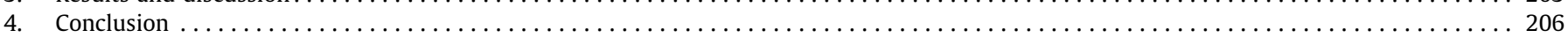

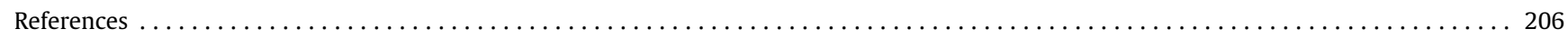

\section{Introduction}

Economically, a mine can contribute to sustainable development by maintaining or enhancing the wellbeing of the local population. For example, a mine can provide a number of economic benefits to a community, including employing residents, utilizing local services, and contributing funds to regional developmental projects (Hilson and Murck, 2000). Throughout the conceptualization, development, operation, and eventual decommissioning of

\footnotetext{
* Corresponding author at: UFOP - Federal University of Ouro Preto, REDEMAT, Escola de Minas, Praça Tiradentes, 35400000 Ouro Preto, Minas Gerais, Brazil. Tel.: +55 3199571003; fax: +55 3135719080 .

E-mail addresses: reinaldo.brandao@vallourec.com, gomesreinaldobrandao@ gmail.com (R.B. Gomes).
}

mineral resources projects, a wide range of opportunities exist to contribute to sustainable development (Corder et al., 2010). In the mining industry, high-level commitments to adopt sustainability have been made as part of the corporate values of mining companies. Accordingly, although mineral products are essential to contemporary societies and economies, simply meeting market demand for mineral commodities falls far short of meeting society's expectations of the industry (Tuazon et al., 2012). Increased productivity is essential to improve the sustainability of existing operations (Gomes and De Tomi, 2011). In this context, it is important to develop processes that can maximize recovery of existing resources. Moreover, processing plants must be able to beneficiate a variety of ores, ensuring the efficiency of metallurgical processes in three respects: quality, volume, and cost (Reuter, 1999). 
The present study investigates the impact of the quality of iron ore lumps on the production process of a mine, focusing on evaluation of the associated gains in reserve. An application of this principle to the Pau Branco mine is presented, providing a clear example of how the introduction of beneficiation methods can impact upon product quality, cut-off grade, and reserve recovery rate, thus improving the sustainability of an operational mining system.

Until the early twenty-first century, iron ore mines developed in Brazil focused primarily on hematite bodies. These ore bodies typically had over $60 \% \mathrm{Fe}$ and low levels of contaminants (such as $\mathrm{Al}_{2} \mathrm{O}_{3}$ and $\left.\mathrm{SiO}_{2}\right)$, and produced lumps $(>16 \mathrm{~mm})$ with physical, chemical, and metallurgical properties favorable for extraction. In the Quadrilatero Ferrifero Area (QF), Minas Gerais (MG), Brazil, the typical hematite (i.e., high-Fe) deposits have become depleted, which has led to the exploitation of poor-quality BIFs (Vale, 2010) (Fig. 1). Moreover, the increased exploitation of BIFs has necessitated the introduction of new and specific beneficiation processes. For iron ore lumps, this change in source led to increases in the amounts of fines (owing to the greater fragility of BIFs compared to hematite ores) and the contents of $\mathrm{Al}_{2} \mathrm{O}_{3}$ (owing to the contaminants found in clays), and $\mathrm{SiO}_{2}$ present in iron ores (Santos and Brandao, 2003). These factors have exerted negative impacts on the steelmaking process.

Iron production is a long process that involves knowledge of the ore throughout its life cycle, from the production of pig iron to the final product, steel. To date, great efforts have been focused on improving knowledge of iron ore reserves and iron beneficiation (Souza Neto et al., 1998). This has included (i) improving metallurgical processes, (ii) increasing the quality of iron and steel according to market requirements, (iii) optimizing facilities, and, in particular, (iv) lowering the cost of production (Hundertmark, 1996). Iron constitutes about 5\% of the earth's crust, making it the fourth most abundant element. The main iron ores are hematite $\left(\mathrm{Fe}_{2} \mathrm{O}_{3}\right)$, magnetite $\left(\mathrm{Fe}_{3} \mathrm{O}_{4}\right)$, and $\mathrm{BIFs}\left(\mathrm{Fe}_{2} \mathrm{O}_{3} / \mathrm{Fe}_{3} \mathrm{O}_{4}+\mathrm{SiO}_{2}\right)$. BIFs from $\mathrm{QF}$, known locally as itabirites, can be subdivided into siliceous, dolomitic, amphibolitic, and hematite rich BIFs; each of these types exhibits specific behaviors during the beneficiation and metallurgical processes (Rosière et al., 2003).

Geological features (particularly the mineralogy and petrogenesis) of iron ores play an important role in defining the most appropriate methods for their processing. Thus, the characterization of minerals is essential for the optimal use of a mineral resource, because it provides mining engineers with the information required to define the process route. Moreover, such characterization helps to identify inefficiencies and losses associated with existing processes accurately, enabling the optimization of the overall performance of a production system (Araujo et al., 2003).

Improvements in processing methods ensure the continuing competitiveness of the steel industry, minimizing losses in the manufacturing process that occur owing to ore quality changes associated with the transition from hematite to BIFs. Previously, most BIF bodies were considered as waste generated by the production process, resulting in them being rejected and stockpiled throughout the development of operating mines. However, newly developed beneficiation plants are capable of undertaking concentration processes for BIFs. For example, for the fraction between $8 \mathrm{~mm}$ and $16 \mathrm{~mm}$ there are several industrial solutions available, including jigs, drum scrubbers, and log washers. The alternatives to increase recovering metal content from poor iron ore lumps (>16 mm) typically involve grinding: three or four stages of crushing followed by primary and secondary milling stages. These operations imply high energy consumption. Thus, the amount of energy required to produce an iron ore grinded product, suitable for sale as pellet or sinter plant feed is substantially more than an equivalent lump (>16 mm) project (McNab et al., 2009). Besides energy, other costs impact the grinding and concentration of lumps, such as wear and other consumables, labor and maintenance, tailings handling, filtering or storage costs (David, 2007).

\section{Example of application: Beneficiation of BIFs lumps from Pau Branco mine}

The methodology adopted in the present study involved the selection of representative samples of dolomitic and siliceous BIFs from the Pau Branco mine; the lump reserves distribution for this mine is presented in Fig. 2.

Pau Branco started operation in 1982, running a hematite plant with production capacity of $3.2 \mathrm{Mt}$, as the pit developed focused on the hematite body exploration, the strip ratio increased to a unsustainable rate, being the bottleneck the hauling fleet and waste deposition capacities. Accordingly, in 2010, a new plant was installed, including concentration circuits for fines ( $<8 \mathrm{~mm})$ : jigs, spirals and magnetic concentrators. Currently, based on the mineral processes installed, the Pau Branco mine operation applies a cut-off grade of $60 \%$ Fe for the lumps ( $>16 \mathrm{~mm}$ ) and $45 \%$ Fe for fines

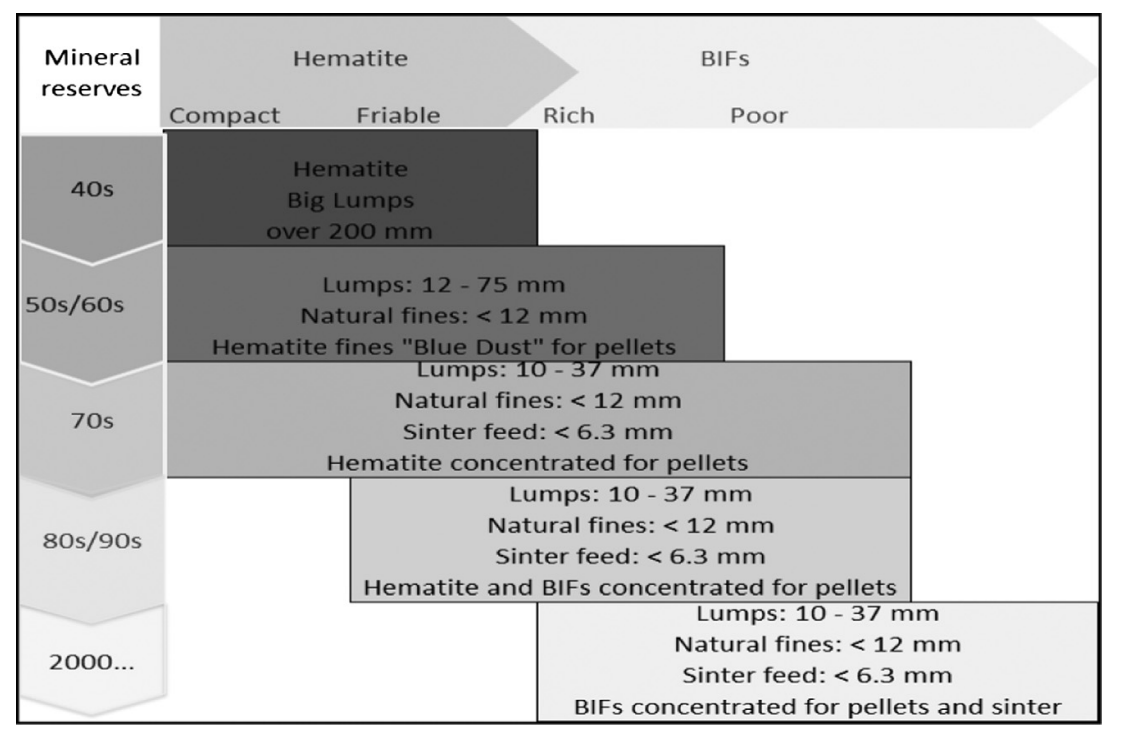

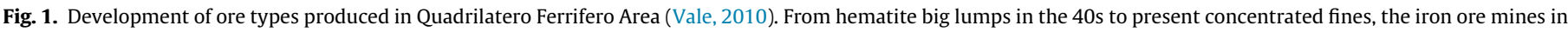
QF Area faced the need of introducing new processes as the percentage of BIFs increased in the composition of the beneficiation plants feeding. 


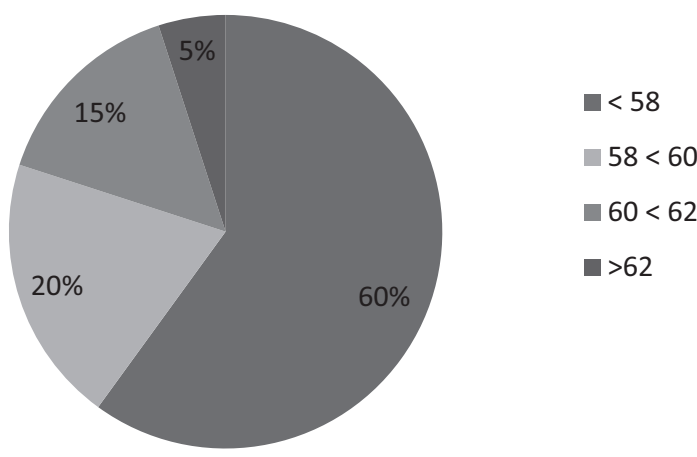

Fig. 2. Distribution of reserves of dolomitic and siliceous BIF lumps in the Pau Branco Mine. The lump reserve between $58 \%$ and $60 \%$ Fe represents $20 \%$ of the total.

( $<8 \mathrm{~mm}$ ). Therefore, mine blocks containing lumps with lower grades are stocked in waste piles. The present study addressed the mineralogical, chemical, and physical characterization of these lumps, in addition to their behavior during processing in jigs, drum scrubbers, and log washers.

To perform the characterization and the beneficiation tests, a total of $2000 \mathrm{t}$ of samples was collected, representing each type of ore. These samples were homogenized, quartered and separated in three batches: $1500 \mathrm{t}$ was used for industrial tests, $1 \mathrm{t}$ for laboratory tests, and the remaining amount kept as a reserve. The $1 \mathrm{t}$ samples were crushed in a jaw crusher with a $100 \mathrm{~m}$ gap and screened using $32 \mathrm{~mm}$ and $16 \mathrm{~mm}$ meshes. The particles with diameter greater than $32 \mathrm{~mm}$ were crushed in a closed circuit. After sample preparation was completed, the samples were submitted to a pilot processing plant and processed using both a log washer and a pneumatic jig. The results were compared to industrial-scale tests involving wet screening and a drum scrubber. The pneumatic jig tests were performed at PCM (Processamento e Caracterização Mineral Ltda, Mariana, MG) and the log washer tests at CDE Global (Cookstown, Ireland). A flow sheet of the processes involved in the tests is showed in Fig. 3.

The separation of minerals in jigs is based on the stratification of particles in an aqueous medium, where ascending and descending water currents fluidize and compress the grains into relatively homogenous layers. Eventually, the lighter grains become concentrated in the upper layers, whereas the heavier grains tend to settle in the lower layers. For ores with a good liberation grade (i.e. more than $75 \%$ of the iron mineral particles are free from contaminants) this concentration method has a high efficiency. Conversely, in log washers and drum scrubbers, beneficiation occurs by attrition of particles, where attrition is defined as the disintegrating effect promoted by relatively weak forces; these forces are weak compared to the strength of comminuting, but strong enough to break unconsolidated conglomerates such as clays or to break bonds between grains (Taggart, 1954). The attrition process can be undertaken when the clay content is too high for stratification or when the material to be separated has a high plasticity index. Using those two methods provides the chance to evaluate the two mechanisms, stratification and attrition, defining the benefits of each one, compared to the wet screening and drum scrubber currently in use at Pau Branco mine.

The operational variables tested in the log washer were adjusted to determine the parameters providing the best performance, which were as follows: $12 \%$ inclination, $100 \mathrm{rpm}$ to define a residence time of $180 \mathrm{~s}$ and the processing water pressure of 0.3 megapascal was used. These parameter values are coherent with the Pau Brancós beneficiation plant capacity and were maintained throughout sample testing. For each type of ore, 15 batches were processed; the results presented are averages of the results for each type.
For the pneumatic jigs, the cut between concentrated and reject was adjusted to a mass recovery of $85 \%$ of the material fed, this target was established as a economic premise of the project. Amplitude was set to $30 \mathrm{~mm}$, with a frequency of 1 cycle per second. The width of the filtering layer was set to $100 \mathrm{~mm}$, this value was indicated by preliminary adjustments to meet the required mass recovery rate, higher widths would decrease the mass recovery, probably beneficiating the quality of the concentrated.

The industrial tests for wet screening and the drum scrubber were performed at Pau Branco's beneficiation plants. For the test in the drum scrubber, the feeding rate was maintained at $100 \mathrm{t} / \mathrm{h}$, $70 \mathrm{rpm}$, and a residence time of $3 \mathrm{~min}$. In the wet screening, the material was fed into a double deck screen with $32 \mathrm{~mm}$ and $16 \mathrm{~mm}$ mesh, at a rate of $150 \mathrm{t} / \mathrm{h}$ to replicate the typical operational variables values of the plant operation.

Mineralogical characterization was performed by point counting, using reflected light microscopy. The preparation of the samples included (1) cutting, trimming and grinding at $0.03 \mathrm{~mm},(2)$ mounting and embedding, (3) grinding and impregnation, (4) regrinding at $0.015 \mathrm{~mm}$, and (5) polishing. A light-reflected microscopy (Leica, model MPS30) with a magnification of 200 times was used for the particles counting. Fractions below and above 325 \# were used, and at least 500 particles of each phase were identified and counted. The volumetric percentages were converted into weight percentages using the theoretical densities of each mineral. The method utilized for the chemical compositional analysis was the X-ray fluorescence [XRF] spectrometry by the fused bead technique. For this analysis, a $0.5-1.0 \mathrm{~g}$ portion of finely ground and ignited iron ore was mixed with lithium metaborate in the ratio $1: 10$ (sample:borate) and the mixture was fused and cast into a circular glass bead. The resultant test sample was subsequently subjected to multi-element analysis by XRF spectrometry. Multielement analysis of iron ore lumps provided the overall concentrations of the main constituents of the product.

\section{Results and discussion}

The dolomitic BIFs, which are composed primarily of hematite and martitic goethite, were found to exhibit lower levels of silica and higher loss on ignition (LOI), compared to siliceous BIFs. More abundant clays were observed in the dolomitic samples, associated with the presence of earthy goethite with high levels of LOI (Santos and Brandao, 2003). Moreover, the degree of liberation was found to be high compared to that for siliceous BIFs. Conversely, the siliceous BIFs were found to be predominantly friable, consisting primarily of martitic and granular hematite and quartz, with minor goethite (Rosière et al., 2003). The mineralogical characterization of the samples is presented in Table 1 below.

Figs. 4 and 5 present photomicrographs of the dolomitic and siliceous BIF samples of the Pau Branco deposit, respectively, illustrating the presence of quartz in siliceous BIFs, in addition to their greater fragility. Moreover, these photomicrographs clearly illustrate the greater amounts of goethite associated with clays in the dolomitic BIFs.

The results of the chemical analyses are presented in Table 2, and demonstrate the existence of a strong negative correlation between total iron and silica. It is also clear that LOI contents are higher in the dolomitic BIFs owing to the greater presence of goethites and clays.

In the tests conducted in the log washer, total disintegration of clay particles was observed owing to the considerable attrition between particles and between the particles and the blades of the equipment. This is in agreement with the decrease in LOI and $\mathrm{Al}_{2} \mathrm{O}_{3}$ and the consequent increase in $\mathrm{Fe}$ content. The quality of the obtained products is shown in Table 3 . 


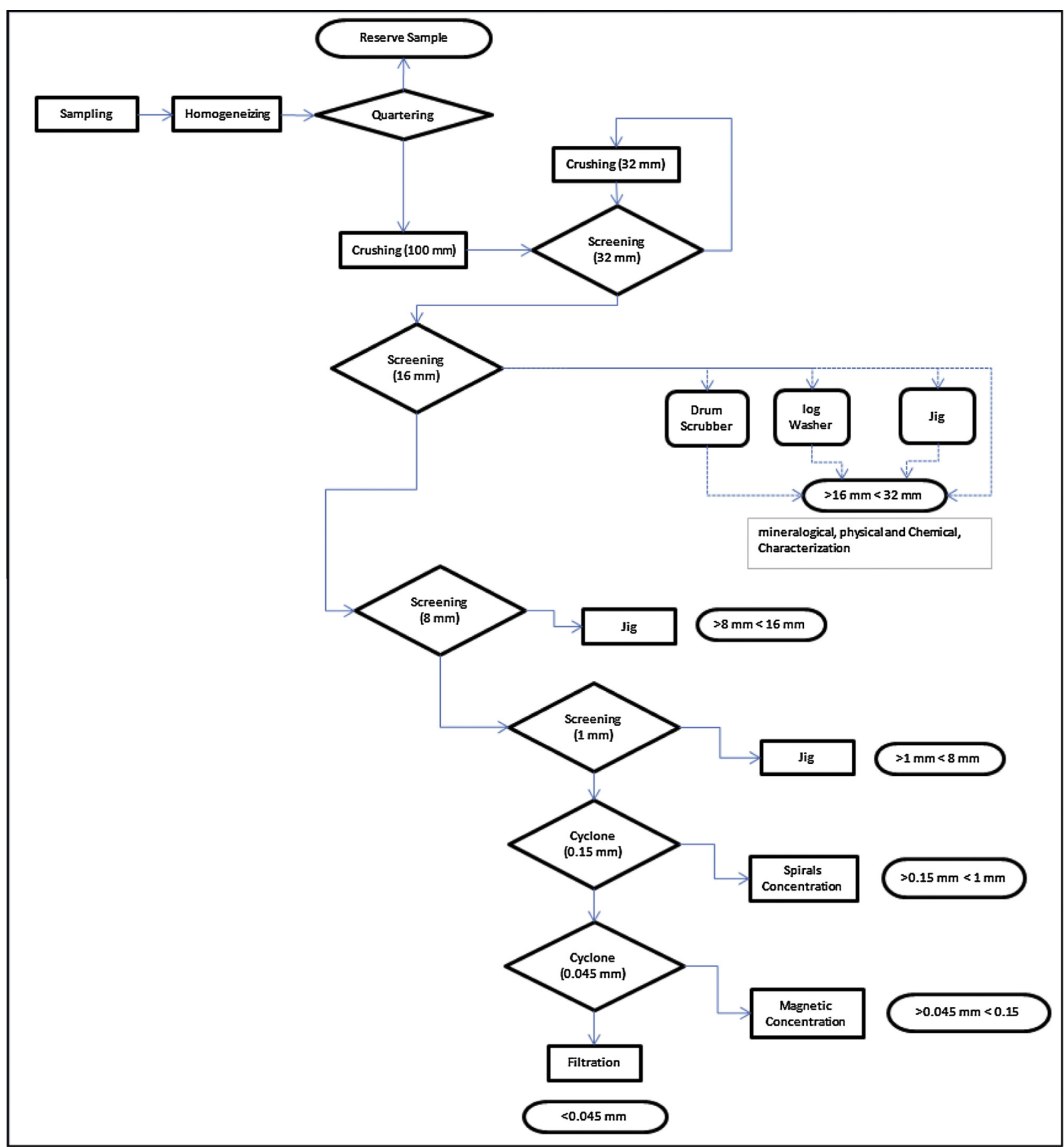

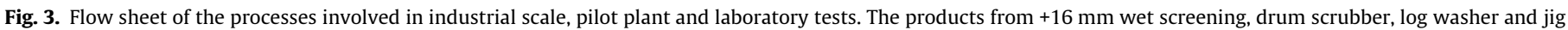
were submitted to chemical, physical and mineralogical characterization.

In the pneumatic jig, iron content increased owing to the elimination of clay and quartz free particles, which would have had low densities. However, the stratification process, responsible for the concentration of Fe was impacted negatively by the generation of fines from the clay particles. The resulting clay material created a pulp, which hindered the stratification of the particles. This was observed primarily during the processing of dolomitic BIFs, where clay particles were more abundant. Because both sample types exhibited high degrees of liberation (i.e., over 94\%), particles with high contents of $\mathrm{Al}_{2} \mathrm{O}_{3}, \mathrm{SiO}_{2}$, and LOI were eliminated, increasing the Fe content of the final product. In the jig, the final product mass was small compared to that of the feed (i.e., mass recovery was relatively low) because of reject generation. However, it may be possible to grind or crush the rejected material and feed it into another concentration process, such as spirals, flotation, or magnetic concentration.

In all of the tests, increases in Fe content and decreases in $\mathrm{Al}_{2} \mathrm{O}_{3}$ and LOI were observed owing to the clays present in the ore types investigated; decreases in the percentage of fines $(<6.3 \mathrm{~mm})$ were also observed. In the log washer, the fine aggregates were released and washed following extensive attrition. Conversely, in the jig, the fines (i.e., the lighter particles) were separated out as reject. Based on the gains in product quality that could be obtained by introducing the processes analyzed here into existing plants, and 
Table 1

Mineralogical semi-quantitative analyses, showing degree of liberation of quartz in iron ore samples, defined by optical microscopy.

\begin{tabular}{lcc}
\hline Ore & Siliceous & Dolomitic \\
\hline Especular hematite & 0.31 & 0.15 \\
Lamelar hematite & 0.4 & 0.12 \\
Lobular hematite & 48.34 & 0.61 \\
Martitic hematite & 15.41 & 56.17 \\
Magnetite & 5.34 & 13.05 \\
Goethite & 19.86 & 21.8 \\
Earthy goethite & 1.7 & 2.17 \\
Free quartz & 7.23 & 5.66 \\
Caulinite & 0.13 & 0.12 \\
Gbsite & 0.28 & 0.15 \\
Quartz liberation degree & 94.51 & 99.96 \\
\hline
\end{tabular}

considering the quality of the lithologies and reserves examined, the cut-off grade for lump ore could feasibly be lowered from $60 \%$ to $58 \%$ Fe. Thus, a gain of up to $20 \%$ in the volume of lump reserves can be projected for the Pau Branco mine.

A preliminary economic study showing the NPV of two potential alternatives, relative to the base case, where the cut off grade is $60 \%$ $\mathrm{Fe}$, is showed in Table 4. Alternative 01, considered the introduction of a typical crushing installation to reduce the lump size to $-16 \mathrm{~mm}$ to be treated in jigs, spirals and magnetic concentration, with an estimated cost of $3 \mathrm{USD} / \mathrm{t}$ processed. In this case, a mass recovery factor of $70 \%$ was considered, meaning that, for each ton fed, $1.4 \mathrm{t}$ of product is generated. The margin contribution of the product was $30 \mathrm{USD} / \mathrm{t}$. Scenario 02 , considered the use of a log washer and jig plant to process the lump. In this scenario, a mass recovery of $90 \%, 0.5 \mathrm{USD} / \mathrm{t}$, and $75 \mathrm{USD} / \mathrm{t}$ of margin contribution
Table 2

Chemical composition and loss on ignition (LOI) for iron ore samples.

\begin{tabular}{lcc}
\hline Element & Siliceous & Dolomitic \\
\hline $\mathrm{Fe}$ & 58.6 & 62.3 \\
$\mathrm{SiO}_{2}$ & 12.2 & 3.90 \\
$\mathrm{Al}_{2} \mathrm{O}_{3}$ & 0.79 & 1.11 \\
$\mathrm{Mn}$ & 0.14 & 0.09 \\
$\mathrm{LOI}$ & 2.40 & 5.90
\end{tabular}

Table 3

Results from tests conducted for siliceous and dolomitic BIFs in wet screening, drum scrubber, pneumatic jig, and log washer.

\begin{tabular}{llllll}
\hline & $\mathrm{Fe}$ & $\mathrm{SiO}_{2}$ & $\mathrm{Al}_{2} \mathrm{O}_{3}$ & LOI & $<6.3 \mathrm{~mm}$ \\
\hline $\begin{array}{l}\text { Wet screening } \\
\text { Siliceous }\end{array}$ & 61.95 & 5.65 & 1.70 & 1.69 & 6.49 \\
$\quad$ Dolomitic & 61.63 & 3.40 & 2.10 & 5.23 & 5.95 \\
Drum scrubber & & & & & \\
$\quad$ Siliceous & 62.53 & 5.02 & 1.31 & 1.12 & 5.97 \\
$\quad$ Dolomitic & 62.49 & 3.05 & 1.45 & 4.19 & 5.65 \\
Pneumatic jigue & & & & & \\
$\quad$ Siliceous & 64.54 & 4.48 & 0.99 & 1.07 & 5.68 \\
$\quad$ Dolomitic & 62.97 & 3.20 & 0.82 & 3.91 & 6.44 \\
Log washer & & & & & \\
$\quad$ Siliceous & 63.39 & 4.68 & 0.84 & 1.09 & 4.71 \\
Dolomitic & 64.03 & 2.36 & 0.79 & 3.71 & 4.09
\end{tabular}

were estimated. In both scenarios a discount rate of $10 \%$ and a lifetime of 5 years were considered.

Other mines, within the QF Area, where the same ore types are present, can benefit from jig and log washer process to also increase their lump reserves and NPV. Thereby, iron ore mines
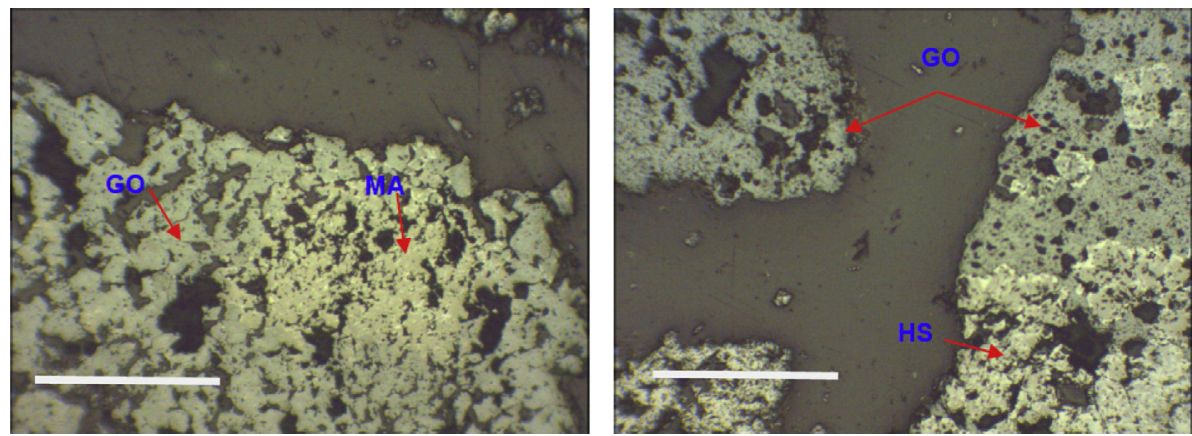

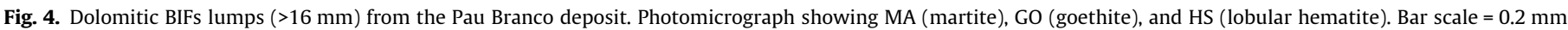
$(35 \times$, crossed Nicols).
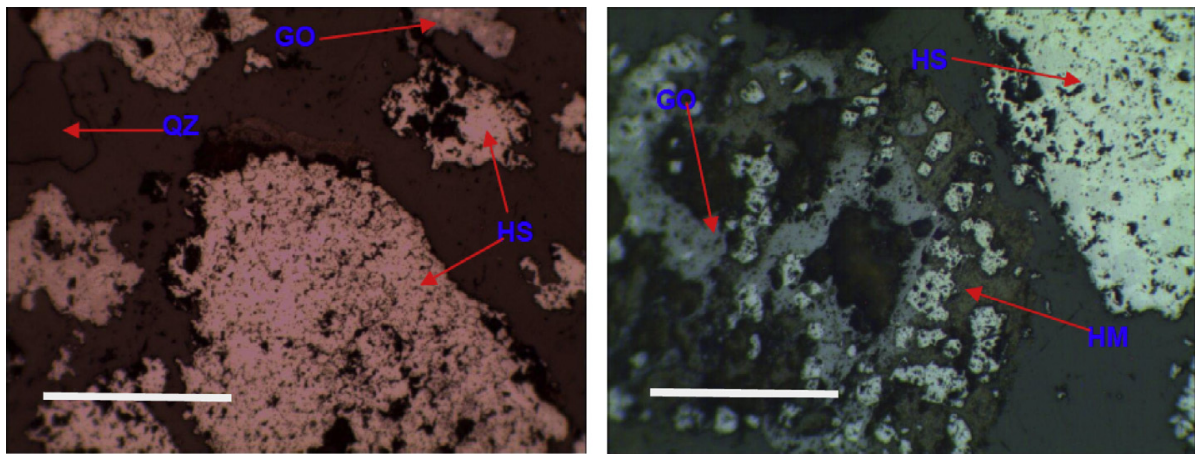

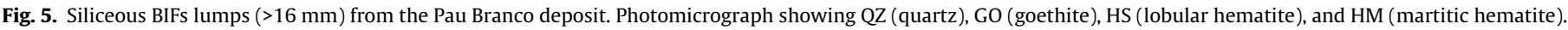
Bar scale $=0.2 \mathrm{~mm}(35 \times$, crossed Nicols $)$. 
Table 4

Preliminary economic study of alternatives to increase the iron recovery from Pau Branco mine reserves.

\begin{tabular}{cccl}
\hline & NPV (M USD) & CAPEX (M USD) & $\begin{array}{l}\text { Pay Back } \\
\text { (years) }\end{array}$ \\
\hline $\begin{array}{c}\text { Alternative 01 } \\
(<16 \mathrm{~mm})\end{array}$ & -1.17 & 15.00 & - \\
$\begin{array}{c}\text { Alternative 01 } \\
(>16 \mathrm{~mm})\end{array}$ & 46.25 & 5.50 & 0.20 \\
\hline
\end{tabular}

can increase their reserve recovery rate, decreasing the waste generation, contributing to the sustainability of the industry.

\section{Conclusion}

In terms of improving the sustainability of mining operations, maximizing the recovery of reserves represents a great opportunity for today's mining industry. In particular, the introduction of new beneficiation processes offers the opportunity to decrease the cut-off grade of a mine, helping to maximize reserve volume.

Pau Branco mine, a medium sized iron ore mine in the Quadrilatero Ferrifero Area has a production capacity of $4.2 \mathrm{Mt}$ per year. Its currently installed processes imply a cut off grade of $45 \% \mathrm{Fe}$ for the fines $(<8 \mathrm{~mm})$, and $60 \% \mathrm{Fe}$ for the lumps $(>12 \mathrm{~mm})$. The cut off grade impacts the recovery of lumps and the generation of waste. As the waste disposition capacity is a bottleneck for the process, the sustainability of the operation is limited by the lump recovery.

In the present study, samples of lumps $(>16 \mathrm{~mm})$ of dolomitic and siliceous BIF ores from the Pau Branco mine were mineralogical and chemically characterized and tested in log washers and pneumatic jigs; then, the potential economic gain in reserves offered by the introduction of these processes was evaluated. For comparison, the industrial processes involving wet screening and a drum scrubber were investigated.

In all tests, gains in Fe content were achieved through the elimination of clay particles and quartz. Moreover, the contents of $\mathrm{Al}_{2} \mathrm{O}_{3}$, LOI, and fines $(<6.3 \mathrm{~mm})$ were reduced. For dolomitic BIFs, $\log$ washer processing resulted in degradation of the clay particles, reducing the LOI content and percentage of fines $(<6.3 \mathrm{~mm})$. Conversely, in the jig, the clay and silica particles were eliminated in the waste owing to their lower densities. For a mixture composed of both siliceous and dolomitic BIFs, a combination of log washers and jigs is recommended, because these equipment types generated gains in both ore types evaluated.

Based on the gains in product quality found here, a $20 \%$ increase in the volume of lumps reserve $(>16 \mathrm{~mm})$ can be estimated, assuming reduction of the mining cut-off grade from $60 \%$ to $58 \%$. Thus, a percentage of the lump ore that is presently destined to end up on waste piles can, in fact, be processed, consequently increasing the NPV by $46.25 \mathrm{M}$ USD, ensuring sustainability of Pau Branco mine operation.

The results presented here will be applied in a project for the geometallurgical characterization of lumps, thus helping to optimize the mine system and achieve gains in sustainability through maximum utilization of reserves, the generation of less waste, and the reduction of environmental impact and production costs of both mineral and metallurgical processes. This project will be presented in a future paper.

\section{References}

Araujo, A.C., Amarante, S.C., Souza, C.C., Silva, R.R.R., 2003. Ore mineralogy and its relevance for selection of concentration methods in processing of Brazilian iron ores. Miner. Process. Extr. Metall. 112 (1), C54-C64.

Corder, G.D., McLellan, B.C., Green, S., 2010. Incorporating sustainable development principles into minerals processing design and operation: SUSOP ${ }^{\circledR}$. Miner. Eng. $23,175-181$.

David, D., 2007. The importance of geometallurgical analysis in plant study, design and operational phases. In: Proceedings Ninth Mill Operators' Conference 2007. The Australasian Institute of Mining and Metallurgy, Melbourne, pp. 241-248.

Gomes, R.B., De Tomi, G., 2011. Metodologia para estimativa e gestão da produtividade de lavra. REM. Revista Escola de Minas (Impresso) 64, 77-83.

Hilson, G., Murck, B., 2000. Sustainable development in the mining industry: clarifying the corporate perspective. Resour. Policy 26, 227-238.

Hundertmark, A., 1996. Reflexões sobre o desenvolvimento do tratamento de minério de ferro e perspectivas sobre a tecnologia do future. In: I Simpósio Brasileiro de Minério de Ferro, Ouro Preto, Anais, pp. 629-654.

McNab, B., Jankovic, A., David, D., Payne, P., 2009. Processing of magnetite iron ores - comparing grinding options. In: Proceedings of Iron Ore 2009 Conference, Perth, Australia, 27-29 July, pp. 277-288.

Reuter, M.A., 1999. The simulation of industrial ecosystems. Miner. Eng. 11, $891-$ 918.

Rosière, C.A., Seshadri, V., Lagoeiro, L.E., Vieira, C.B., 2003. Geological characteristics of iron ores from Quadrilátero Ferrífero. In: 1st International Meeting On Ironmaking, Abm, Belo Horizonte, Anais, pp. 49-55.

Santos, L.D., Brandao, P.R.G., 2003. Morphological varieties of goethite in iron ores from Minas Gerais, Brazil. Miner. Eng. 16, 1285-1289.

Souza Neto, A.N., Capolari, L., Silva Neto, P.P., 1998. Ênfase da pesquisa de minério de ferro no centro de pesquisas da CVRD. In: XXIX Seminário De Redução De Minério De Ferro-Xiii Seminário De Controle Químico Em Metalurgia - Ix Seminário De Carboquímicos, ABM, Belo Horizonte, Anais, pp. 681-687.

Taggart, A.F., 1954. Handbook of Mineral Dressing: Ore and Industrial Minerals. John Wiley \& Sons Inc, Sydney.

Tuazon, D., Corder, G.D., Powell, M., Ziemski, M.A., 2012. Practical and rigorous approach for the integration of sustainability principles into the decisionmaking processes at minerals processing operations. Miner. Eng. 29, 65-71.

Vale, 2010. Cadeia de valor do minério de ferro e os benefícios do desenvolvimento do corredor logístico para a região: AMERICAS IRON ORE. In: The 3rd Annual Americas Iron Ore Conference 9-11 November 2010, Rio de Janeiro, Brazil. <http://pt.slideshare.net/FabianoPessanha/apresvale2009> (accessed 05.05.13). 